\title{
Trace metal concentrations in the muscle of seven marine species: Comparison between the Gulf of Lions (North-West Mediterranean Sea) and the Bay of Biscay (North-East Atlantic Ocean)
}

\author{
Mille Tiphaine ${ }^{1,{ }^{*}}$, Cresson Pierre ${ }^{2}$, Chouvelon Tiphaine ${ }^{3}$, Bustamante Paco ${ }^{4}$, \\ Brach-Papa Christophe ${ }^{1}$, Bruzac Sandrine ${ }^{3}$, Rozuel Emmanuelle ${ }^{3}$, Bouchoucha Marc ${ }^{1}$
}

${ }^{1}$ Ifremer, Unité Littoral, Laboratoire Environnement Ressources Provence Azur Corse, Zone portuaire
de Brégaillon, CS 20330, 83507 La Seyne sur Mer Cedex, France
${ }^{2}$ Ifremer, Unité Halieutique de Manche-Mer du Nord, Laboratoire Ressources Halieutiques de
Boulogne, 150 quai Gambetta, 62200 Boulogne sur Mer, France
${ }^{3}$ Ifremer, Unité Biogéochimie et Écotoxicologie, Laboratoire de Biogéochimie des Contaminants
Métalliques, rue de I'lle d'Yeu, BP 21105,44311 Nantes Cedex 03, France
${ }^{4}$ Littoral Environnement et Sociétés (LIENSs), UMR 7266 CNRS-Université de La Rochelle, 2 rue
Olympe de Gouges, 17042 La Rochelle Cedex 01, France

* Corresponding author : Tiphaine Mille, email address : tiphaine.mille@ifremer.fr

\begin{abstract}
:
Concentrations of 6 trace metals ( $\mathrm{Ag}, \mathrm{Cd}, \mathrm{Cu}, \mathrm{Ni}, \mathrm{Pb}, \mathrm{Zn}$ ) in the muscle of 2 sharks (Galeus melastomus and Scyliorhinus canicula), 4 teleosts (Helicolenus dactylopterus, Lepidorhombus boscii, Micromesistius poutassou and Phycis blennoides) and 1 crustacean (Nephrops norvegicus) were compared between the Bay of Biscay (Atlantic Ocean) and the Gulf of Lions (Mediterranean Sea). Although average concentrations and the trace element pollution index were generally higher in the Gulf of Lions, significant differences between the two ecosystems were only found for $\mathrm{Zn}$ for Helicolenus dactylopterus, and for $\mathrm{Ag}$ and $\mathrm{Cu}$ for the crustacean $\mathrm{N}$. norvegicus. Moreover, some relationships between trophic level or size and metal concentrations were found for these two species. The absence of clear pattern may result from the blurring effect of contamination and excretion that may act differentially for all species and all elements.
\end{abstract}

\section{Highlights}

- Low concentrations of trace metals in the muscle tissue for all studied marine species $>$ Absence of clear patterns for all studied species and elements - Metal concentrations were mainly higher in the Gulf of Lions than in the Bay of Biscay.

Keywords : Inorganic elements, Contamination, Bioaccumulation, Fish Shark, Norway lobster 
Trace metals are naturally present in the Earth crust and as such they are natural components of the marine environment (Bryan, 1971; Mason, 2013). They differ fundamentally in their metabolic role and their regulation by aquatic organisms (Amiard et al., 1987). Some trace metals such as copper $(\mathrm{Cu})$ or zinc $(\mathrm{Zn})$ are involved in essential metabolic purposes including functional and structural role. These essential trace metals are generally regulated by aquatic organisms. On the contrary, trace metals such as cadmium $(\mathrm{Cd})$ or lead $(\mathrm{Pb})$ are not essential for marine life (i.e. no known biological role) and need to be detoxified or excreted when absorbed (Rainbow, 2002). Whether essential or non-essential, they become toxic beyond a certain threshold (Amiard et al., 1987). Since marine organisms are able to accumulate trace metals, some of them like fish are sometimes considered relatively good semi-quantitative bioindicators, reflecting the occurrence and bioavailability of contaminants in areas where they live (Raknuzzaman et al., 2016). However, trace metal concentrations in marine organisms result of a balance between their uptake and excretion processes (Gobert et al., 2017; Guven et al., 1999). Bioaccumulation, namely the capacity of an organism to concentrate a trace metal in its tissues, depends on the uptake from water by direct contact (e.g. through epidermis, gills, digestive tract) but also from diet (e.g. Mathews and Fisher, 2009; Xu and Wang, 2002). Therefore, an accurate knowledge of the organic matter sources fueling food webs and their associated contamination level is crucial to understand organisms' contamination (Hall et al., 1997). Moreover, several biological factors such as length or age can affect diet (Chouvelon et al., 2014), and consequently affect potential dietary inputs of trace metals for consumers, in addition to the fact that the age of organisms directly influences their chronic exposure to contaminants (Cresson et al., 2015). Fish bioaccumulation pattern is thus a complex process that can vary according to food resources, feeding habitats, and metabolic activity of species, as well as according to the physical/chemical conditions of water column that can directly affect the bioavailability of trace metals.

In addition, some trace metals such as mercury $(\mathrm{Hg})$ are well-known for their biomagnification property, namely the trend for increasing concentrations along food webs (Bryan et al., 1979). This process in particular is responsible for the high trace metal concentrations generally 
observed in high trophic level species such as marine predators or long-lived species (Endo et al., 2008), which implies a high toxicological hazard for humans when consuming top predator organisms like piscivorous fishes (Damiano et al., 2011). This high hazard linked with Hg in marine systems drove a major research effort on this metal, in order to understand the influence of abiotic (e.g. habitats of species; (Chouvelon et al., 2012)) and biotic factors (e.g. fish growth, trophic functioning of ecosystems; (Chouvelon et al., 2018; Cossa et al., 2012; Cresson et al., 2014) on Hg bioaccumulation in marine organisms, especially in commercial species. As such, several authors evidenced and partly explained the "Mediterranean Hg anomaly", i.e. the fact that species in the Mediterranean have higher $\mathrm{Hg}$ concentration than their counterparts from other environments (Cossa et al., 2012; Cossa and Coquery, 2005). Contrary to $\mathrm{Hg}$, such spatial differences for other trace metals were only studied for few species such as the deep-water shark Galeus melastomus (Hornung et al., 1993) or the pelagic swordfish Xiphias gladus (Damiano et al., 2011).

In this context, this study aimed to document and compare the bioaccumulation of trace metals (other than $\mathrm{Hg}$ ) in the muscle of several common species with commercial interest between the Bay of Biscay (BoB) in the north-eastern Atlantic Ocean and the Gulf of Lions (GoL) in the north-western Mediterranean Sea. An original approach is reported in this study, relying on an interspecific comparison between several taxa such as crustacean species, teleost and chondrichthyan fish, but also on the comparison of bioaccumulation patterns between essential and non essential trace metals.

Samples were collected during two bottom trawling surveys operated by the French institute for the exploitation of the sea (Ifremer), MEDITS in the GoL in 2012 (Jadaud and Metral, 2012) and EVHOE (Leaute et al., 2008) in the BoB in 2008 (Figure 1). These two ecosystems have been chosen for their differences in terms of trophic status (i.e. mesotrophy vs. oligotrophy; (Liénart et al., 2017) but also in terms of probable contamination, since the BoB is open onto the Atlantic Ocean while the GoL is part of the Mediterranean semi-enclosed sea. In addition, both ecosystems are major areas for fisheries, for which trace metal concentrations in 
commercial species may be of concern. Finally, they are two out the four French marine subregions considered and monitored by the European Marine Strategy Framework Directive. The studied species included one crustacean species - the Norway lobster (Nephrops norvegicus, Linnaeus, 1758)-, four teleost fish - the blackbelly rosefish (Helicolenus dactylopterus, Delaroche, 1809), the four-spot megrim (Lepidorhombus boscii, Risso, 1810), the blue whiting (Micromesistius poutassou, Risso, 1827) and the greater forkbeard (Phycis blennoides, Brünnich, 1768)-, and two sharks - the black-mouthed dogfish (Galeus melastomus, Rafinesque, 1810) and the lesser spotted dogfish (Scyliorhinus canicula, Linnaeus, 1758)-. These species are largely present on the shelf-edge in both ecosystems, allowing direct comparisons. They were chosen based on their importance in the communities of both systems, their relatively high trophic position (Papiol et al., 2013) and their commercial interest. Individuals have been collected at depth ranging between 284 and $816 \mathrm{~m}$ in the GoL and between 47 and $511 \mathrm{~m}$ in the $\mathrm{BoB}$ (Table 1). Individuals were stored frozen on board and kept frozen until dissection. At the laboratory, individuals were thawed and measured to the nearest $\mathrm{mm}$ (cephalothorax length for $N$. norvegicus and total length for other species). Two muscle samples without skin and bones were taken on all individuals for isotopic (i.e. carbon and nitrogen stable isotope ratios) and trace metal analyses. For sharks and teleosts, the white dorsal muscle was used for analyses whereas for $N$.norvegicus, the thoracic muscle was taken out. Due to the amount of matter needed for the analysis of trace metal concentrations $(\sim 200 \mathrm{mg}$ of dry muscle tissue), several small individuals with similar parameters (sampling site, sex and size) were pooled. Mean length and isotopic ratios were used for these pools of individuals (indicated in Table 1). All muscle samples were stored frozen, before freeze-drying and grinding.

Concentrations of three essential trace metals: copper $(\mathrm{Cu})$, zinc $(\mathrm{Zn})$, nickel $(\mathrm{Ni})$, and three non-essentials: silver $(\mathrm{Ag})$, cadmium $(\mathrm{Cd})$, lead $(\mathrm{Pb})$, were measured by Inductively Coupled Plasma-Mass Spectrometry (ICP-MS; Thermo X-Series I), after several steps of sample preparation. Briefly, subsamples $(\sim 200 \mathrm{mg})$ of homogenized dry muscle tissue were digested with a mixture of $3.5 \mathrm{~mL} \mathrm{HNO}_{3}$ and $5 \mathrm{~mL} \mathrm{HCl}$ Suprapur quality, and then heated in a 
microwave oven. After the mineralization process, each sample was completed to $50 \mathrm{ml}$ with milli-Q quality water, and a known quantity of internal standard (indium) was added before analysis. Samples were re-diluted when necessary before analyses. Trace metal analyses were run according to a thorough quality control program including the analysis of Certified Reference Materials (CRMs): DORM-3 and DORM-4 (fish protein, National Research Council Canada), and NIST-2976 (mussel tissue, National Institute of Standards and Technology USA). CRMs were analyzed in the same conditions as the samples and results were in good agreement with the certified values. Limits of quantification (LQ) for $\mathrm{Ag}, \mathrm{Cu}, \mathrm{Cd}, \mathrm{Ni}, \mathrm{Pb}$, and $\mathrm{Zn}$ were $0.05,2.5,0.05,0.25,0.05$ and $15 \mu \mathrm{g} . \mathrm{g}^{-1}$ dry weight, respectively. Sample concentrations are given with two significant figures.

Isotopic analyses were performed on a small subsample of grinded muscle with a Thermo Scientific Delta V Advantage mass spectrometer coupled to a Thermo Scientific Flash EA1112 elemental analyzer. The results are presented in the classical $\delta$ notation, $\delta X=\left(\frac{R_{\text {sample }}}{R_{\text {standard }}}-1\right) \times$ $10^{3}$ where $\mathrm{X}$ is ${ }^{13} \mathrm{C}$ or ${ }^{15} \mathrm{~N}$ and $\mathrm{R}$ the ratio between heavy and light isotopes. Standard is Pee Dee Belemnite for $\delta^{13} \mathrm{C}$ and atmospheric nitrogen for $\delta^{15} \mathrm{~N}$. Based on replicate measurements of internal laboratory standards, the experimental precision was $<0.20 \%$ for both $\delta^{13} \mathrm{C}$ and $\delta^{15} \mathrm{~N}$. The trophic level of each individual $i$ was calculated from isotope values, with the following formula, $T L_{i}=T L_{\text {baseline }}+\frac{\delta^{15} N_{i}-\delta^{15} N_{\text {baseline }}}{T E F}$. TEF (Trophic Enrichment Factor, i.e. the $\delta^{15} \mathrm{~N}$ change between two consecutive trophic levels) was set to 2.3 for sharks, 3.2 for teleosts and 3.4 for $N$. norvegicus in both ecosystems. These values were consistent with literature and results of dedicated experiments, as reviewed by Chouvelon et al., (2012). Regarding the trophic baseline, most recent approaches recommend using primary consumers rather than primary producers, as isotopic ratios of primary producers may be highly variable, whereas primary consumers (i.e. consumers at theoretical trophic level 2) provide a time-integrated information on the organic matter sources actually incorporated in food webs (Jennings and van der Molen, 2015; Trueman et al., 2017). In the Gulf of Lions, the mean value measured for 200-300 $\mu \mathrm{m}$ zooplankton by Espinasse et al. (2014) was used as the trophic baseline (i.e. $\delta^{15} \mathrm{~N}_{\text {baseline }}=$ 
$3.69 \%$ ). Indeed, previous studies demonstrated that shelf-edge Mediterranean food webs are based on falling phytoplanktonic production (Cresson et al., 2014), justifying the use of a pelagic trophic baseline for the Mediterranean organisms considered here. In the BoB, the scallop Pecten maximus was used as the trophic baseline, consistently with the formula developed by Chouvelon et al., (2012) for this ecosystem, to correct for the onshore-offshore effect on the consumers' isotopic ratios $\left(\delta^{15} \mathrm{~N}_{\text {baseline }}=33.47+1.556 \times \delta^{13} \mathrm{C}_{\text {consumer }}\right)$.

The relationships of metal concentrations with length and trophic level were investigated by a linear model including these continuous variables as two potential biological factors driving bioaccumulation and biomagnification, respectively. This analysis allowed to explain both potentially large inter-individual variability but also to avoid bias in the measure of the ecosystem effect. The later was added in the model as factor as well as the interaction with length and trophic level. The model was reduced by a bidirectional elimination procedure based on the Akaike information criteria (AIC) (Borcard et al., 2011). In order to determine active factors, significance of effects in the reduced model was tested by F-tests between nested models respecting marginality of the effects (Fox and Weisberg, 2011). In the case where the size was correlated with the trophic level (as tested by the Pearson correlation coefficient test), only the total length was included in the model. Only trace elements for which more than $70 \%$ of the concentrations were above the LQ have been modeled.

In addition, in order to complete the approach element by element, an index of global contamination was calculated from all element concentration including concentration above the LQ. The Trace Element Pollution Index (TEPI) proposed by Richir and Gobert (2014) has been chosen because this index allows a reliable comparison of global trace element contamination between environments, whatever the studied trace element. The TEPI values were calculated for each species and each environment as follow: TEPI $=\left(C f_{1} \times C f_{2} \ldots C f_{n}\right)^{1 / n}$ where $C f_{n}$ is the mean normalized concentration (individual concentration divided by the mean concentration) of the trace element $n$. All statistical analyses were performed to the error threshold of 5\%, using the "car" (Fox and Weisberg, 2011) "MASS" (Venables and Ripley, 2002) and "PMCMR" (Pohlert, 2014) packages in the statistical environment R Core Team (2017). 
Overall, this study provides baseline information on the concentrations of some trace metals, both essential $(\mathrm{Cu}, \mathrm{Ni}, \mathrm{Zn})$ and non-essential $(\mathrm{Ag}, \mathrm{Cd}, \mathrm{Pb})$, in several marine species from the GoL and the BoB (Table 2). The results are consistent with the pattern of low metal concentrations (metals other than $\mathrm{Hg}$ ) usually found in the muscle tissue, in comparison with other tissues/organs such as liver or kidneys (Canli and Atli, 2003; Dural et al., 2006; ElMoselhy et al., 2014; Endo et al., 2008; Long and Wang, 2005; Mormede and Davies, 2001). Consistently, in the present study, all muscle samples from teleosts and sharks (i.e. fish) displayed $\mathrm{Ag}$ and $\mathrm{Cd}$ concentrations below the quantification limits (Table 2). In general, gills, intestinal viscera, liver and kidneys contain relatively high metal burden, indicating that they likely constitute major organs for metal uptake (gills and intestinal viscera) and final deposition or excretion (liver, kidneys) (Xu and Wang, 2002). Trace element accumulation indeed differs according to organs and as such, Cd tends to be preferentially accumulated in liver and kidney, owing to higher levels of metallothioneins (chelating proteins) that act as sites for $\mathrm{Cd}$ storage in order to protect fish from cellular metal toxicity (Dural et al., 2006; Endo et al., 2008). Consequently, higher $\mathrm{Cd}$ concentrations are generally observed in the liver than in the muscle in fish (Eisler, 2010). Similarly, Ag concentrations in intestinal viscera were shown to be higher than in muscle tissues in the marine fish Terapon jarbua, for instance (Long and Wang, 2005). Here, the muscle was chosen as the edible part mostly consumed in marine organisms, and thus hazardous if contamination is high. In the present study, any sample has metal concentrations above the food safety thresholds determined by the European commission regulation, i.e. 0.05 $\mu \mathrm{g} \mathrm{g}^{-1}$ wet mass and $0.5 \mu \mathrm{g} \mathrm{g}^{-1}$ wet mass for Cd in fish and crustaceans respectively, $30 \mu \mathrm{g} \mathrm{g}^{-1}$ wet mass for $\mathrm{Cu}, 0.2 \mu \mathrm{g} \mathrm{g}^{-1}$ wet mass and $0.5 \mu \mathrm{g} \mathrm{g}^{-1}$ wet mass for $\mathrm{Pb}$ in fish and crustaceans respectively (EC, 2006). This corresponds to threshold values of $0.25 \mu \mathrm{g} \mathrm{g}^{-1}$ dry mass for Cd in fish and $2.5 \mu \mathrm{g} \mathrm{g}^{-1}$ dry mass for $\mathrm{Cd}$ in crustaceans, $150 \mu \mathrm{g} \mathrm{g}^{-1}$ dry mass for $\mathrm{Cu}, 1 \mu \mathrm{g} \mathrm{g}^{-1}$ dry mass for $\mathrm{Pb}$ in fish and $2.5 \mu \mathrm{g} \mathrm{g}^{-1}$ dry mass in crustaceans, if an empirical wet to dry conversion factor of 5 is used. 
Within a given ecosystem, significant differences between species were observed (Figure 2). In addition, the species-dependent pattern was similar between both ecosystems. The highest concentrations were observed for the crustacean N. norvegicus, especially for $\mathrm{Ag}, \mathrm{Cd}$, and $\mathrm{Cu}$. Among fish, the flatfish $L$. boscii had the highest mean $\mathrm{Cu}$ and $\mathrm{Pb}$ concentrations (despite high standard deviations), and the shark S. canicula had the highest $\mathrm{Zn}$ concentrations. These results are in agreement with Younis et al. (2015) that showed higher $\mathrm{Cu}, \mathrm{Cd}, \mathrm{Pb}$ and $\mathrm{Zn}$ concentrations in the muscle of 3 crustaceans such as the spiny lobster Panulirus penicillatus (same suborder that $N$. norvegicus) than in the muscle of 10 demersal fish species in the Red Sea. The high values of $\mathrm{Cu}$ and $\mathrm{Zn}$ for the studied crustacean appear driven by the specific metabolism of this taxon. In crustaceans, $\mathrm{Zn}$ is a key component of many enzymes such as carbonic anhydrase, and $\mathrm{Cu}$ is a functional part of the respiratory protein hemocyanin (Rainbow, 2002). As such, hemolymph, the circulatory liquid of crustaceans is $\mathrm{Cu}$-rich and represents more than $50 \%$ of the $\mathrm{Cu}$ in crustaceans, being also fairly constant with the exception of starvation periods (Depledge and Bjerregaard, 1989). Similarly, high $\mathrm{Zn}$ values measured in the muscle of S. canicula are also consistent with previous studies. Indeed, authors showed experimentally that the bioaccumulation capacity of $\mathrm{Zn}$ from seawater was particularly pronounced in this shark species, resulting in a higher concentration factor for S. canicula than for the teleost turbot Psetta maxima, for instance (Jeffree et al., 2006, 2010). However, the other chondrichtyan species G. melastomus presented lower $\mathrm{Zn}$ concentrations but higher $\mathrm{Cu}$ and $\mathrm{Pb}$ concentrations. Several studies have shown heterogeneity in metal bioaccumulation between chondrichtyan species (e.g. Glover, 1979; Jeffree et al., 2010). Inferring such a pattern for G. melastomus may explain the differences observed between the two shark species, but actual pattern could only be explained by dedicated experiments. Thus, the peculiar metabolism of S. canicula regarding Zn may explain the high values measured excluding local contamination.

In this study, only 7 element concentrations have been modeled, i.e. Zn concentration for $S$. canicula and $H$. dactylopterus and all element concentrations except $\mathrm{Ni}$ for $N$. norvegicus. The crustacean species presented a significant increase of $\mathrm{Ag}$ and $\mathrm{Cd}$ concentrations with increasing 
trophic level of the individuals and also a significant biomagnification of $\mathrm{Cu}$ that differ according to the ecosystem (significant interaction Ecosystem $\mathrm{x}$ Trophic level). In addition, a significant bioaccumulation was observed for $\mathrm{Cu}$ that differed also between ecosystems. In general for crustaceans, $\mathrm{Cd}$ is mainly taken up from water (Rainbow, 1998). This bioaccumulation pattern has been described for different crustacean species such as the barnacle Elminius modestus and the shrimp Palaemon elegans. Thus $\mathrm{Cd}$ is bioaccumulated in a metabolically available form along life and is stored in a detoxified form without excretion process (Rainbow, 2002). As such, the pattern observed in this study for $\mathrm{Cd}$ and $\mathrm{Ag}$ in $N$. norvegicus seems to follow this accumulation pattern. However, all relationships found in the present study must still be confirmed as it is not supported by a large number of samples. For all the fish species studied (both sharks and teleosts), there was no relationship between element concentrations and the total length and/or trophic level except for $\mathrm{Zn}$ concentrations in $H$. dactylopterus, which presented a significant decrease of $\mathrm{Zn}$ concentrations with increasing fish length. This likely suggests low bioaccumulation and trophic transfer of the studied trace metals for these high-trophic level consumers, and/or that their inputs over time are lower than the outputs through excretion, or than the dilution of metal burden with growth, for instance. The absence of relationship between fish size and trace element concentrations, whether essential or non-essential, has been indeed already described in previous studies (Canli and Atli, 2003). The absence of relationships for the essential elements that are $\mathrm{Zn}$ and $\mathrm{Cu}$ in particular likely indicates that the body concentrations are regulated and maintained at a certain concentration (Canli and Atli, 2003; Hornung et al., 1993). However, a negative relationship was already observed (Endo et al., 2008), and may be explained by a higher metabolic activity in fastgrowing young individuals, requiring higher amount of these elements than older individuals. Similarly, concentrations of non-essential elements such as $\mathrm{Cd}$ or $\mathrm{Pb}$ tend to decrease or to show non-significant trends with increasing fish size and/or trophic level, probably due to higher excretion rate and/or dilution of metal burden with growth, and lower metabolism (Eisler, 2010). In the present study, for both ecosystems, the fish size range represented through the sampling rather concerned fishes with large size (i.e. more adults than juveniles), which could 
explain the absence of this significant relationship due to the lack of juvenile fish in our sampling. A similar absence of significant relationship was nevertheless recently observed for a Mediterranean scorpionfish over a larger size range, demonstrating that the pattern observed in the present study may not be so biased by the sample size (Ourgaud et al., 2017). Finally, biomagnification likely depends on the bioavailability of metals in prey or food sources, on the trace metal assimilation efficiency of predators, on food web complexity and on its species composition (Wang, 2002). Most trace metals (with the exception of cesium (Cs) and $\mathrm{Hg}$ ) do not biomagnify along aquatic food webs (Xu and Wang, 2002), which is supported here by the absence of relationship between element concentrations and trophic level. In addition, the pattern observed here in muscle tissues may be blurred by the preferential bioaccumulation of metals in liver or kidneys, as commented above.

For each species, mean concentrations of most of the trace metals studied were higher in the GoL than in the BoB (Table 3, Figure 2). Moreover, this trend is confirmed by the TEPI values. All species combined, the TEPI values were higher in the GoL (1.13) than in the BoB (0.70), as it was the case for the majority of TEPI calculated when each species was considered separately (Table 2). This pattern is consistent with previous studies on trace metal contamination such as $\mathrm{Hg}$ (Chouvelon et al., 2018; Cossa and Coquery, 2005; Harmelin-Vivien et al., 2009) but also $\mathrm{Cd}$ and $\mathrm{Pb}$ (Damiano et al., 2011). In our study, only H. dactylopterus and $N$. norvegicus presented significant difference of metal concentrations between both locations (Table 3). For H. dactylopterus, mean $\mathrm{Zn}$ a concentration was $18.7 \pm 2.7 \mu \mathrm{g} . \mathrm{g}-1$ in the GoL and was significantly higher than in the $\mathrm{BoB}$, where the values were all below the quantification limit. Mean $\mathrm{Ag}$ concentration and $\mathrm{Cu}$ concentration for N. norvegicus were significantly higher in the $\operatorname{GoL}\left(1.060 \pm 0.477 \mu \mathrm{g} \cdot \mathrm{g}^{-1}\right.$ and $61.9 \pm 25.1 \mu \mathrm{g} \cdot \mathrm{g}^{-1}$, respectively $)$ than in the $\mathrm{BoB}(0.512 \pm 0.191$ $\mu \mathrm{g} . \mathrm{g}^{-1}$ and $12.6 \pm 4.7 \mu \mathrm{g} \cdot \mathrm{g}^{-1}$, respectively). These results could be explained by three potential hypotheses. First, differences of trace metal concentrations may result from higher sediment concentrations in the GoL than in the BoB. Bentho-demersal species as the ones used in the present study forage near or at the surface of the sediment, and may thus be influenced by 
chemical contamination in the sediment. Mean values measured in the sediment within the French network of chemical contamination monitoring ("ROCCh", ex "RNO") were found to be higher in the GoL $\left(\mathrm{Ni}=30 \mu \mathrm{g} \cdot \mathrm{g}^{-1}, \mathrm{Cu}=16.5 \mu \mathrm{g} \cdot \mathrm{g}^{-1}, \mathrm{~Pb}=31 \mu \mathrm{g} \cdot \mathrm{g}^{-1}\right.$ and $\mathrm{Zn}=78.5 \mu \mathrm{g} \cdot \mathrm{g}^{-1}$ dry weight) than in the south of the $\mathrm{BoB}$ (the Landes and the Basque coasts: $\mathrm{Ni}=13.3 \mu \mathrm{g} \cdot \mathrm{g}^{-1}, \mathrm{Cu}=$ $7.1 \mu \mathrm{g} \cdot \mathrm{g}^{-1}, \mathrm{~Pb}=24.1 \mu \mathrm{g} \cdot \mathrm{g}^{-1}$ and $\mathrm{Zn}=79.3 \mu \mathrm{g} \cdot \mathrm{g}^{-1}$ dry weight), which might support this hypothesis. A similar pattern was observed in the present study for $\mathrm{Cu}$ and $\mathrm{Ni}$ in organisms (crustaceans and fish), with concentrations two times higher in the GoL than in the BoB. Secondly, this pattern of generally higher metal concentrations in individuals from the GoL than from the $\mathrm{BoB}$ is consistent with previous studies on other contaminants such as $\mathrm{Hg}$, which highlighted the prevalent effect of oligotrophy, driving higher contamination levels, lower organisms' size and lower $\mathrm{C}$ and $\mathrm{N}$ stable isotope ratios in the Mediterranean (i.e. lower biodilution effect of contaminants in general through the food web) (Chouvelon et al., 2018; Cossa et al., 2012; Harmelin-Vivien et al., 2009). This is also observed in this study where the majority of metal concentrations were on average higher in the GoL than in the $\mathrm{BoB}$, along with lower total lengths and trophic levels, likely revealing the crucial role of sources of organic matter and primary producers at the base of the food web in the bioaccumulation and trophic transfer of metals (for more details, see (Chouvelon et al., 2018). Thirdly, an increasing number of studies have documented relatively high levels of trace metal contamination in shelf-edge or deep species (Cronin et al., 1998; Hornung et al., 1993), especially when compared to neritic species (Chouvelon et al., 2012). In this study, samples from the GoL were caught deeper than BoB samples. This may also explain the highest species contamination observed in the GoL by a potential effect of the depth on trace metal concentrations, where remineralization and/or transformation and modification of the bioavailability of scavenging elements may occur (e.g. for $\mathrm{Hg}$, Heimbürger et al., 2010).

In summary, this study investigated and compared the concentrations of six trace metals in the muscle of seven species including one crustacean, two chondrichtyan and four teleost species 
between the Atlantic Ocean and the Mediterranean Sea. The highest concentrations were found in samples from the GoL (i.e. Mediterranean), confirmed by the use of a more global pollution index (TEPI). Although the difference is less marked than the pattern previously observed for $\mathrm{Hg}$ (Chouvelon et al., 2018), these results seem to confirm the peculiarity of the Mediterranean Sea concerning trace metals. Additionally, relationships between the concentrations of the six analyzed trace metals and total length or trophic level were never significant for fish, except one for one fish ( $\mathrm{Zn}$ concentrations in $\mathrm{H}$. dactylopterus). A significant increase of $\mathrm{Ag}, \mathrm{Cd}$ and $\mathrm{Cu}$ concentrations in the muscle with increasing trophic level, and a significant decrease of $\mathrm{Cu}$ with increasing length were observed for the crustacean only. The absence of clear patterns may be largely due to the confounding effects of element integration, metabolic regulation and excretion mechanisms, more complex for these trace metals than for exclusive contaminants like $\mathrm{Hg}$ or Cs. Further work based on the concentrations of these trace metals in the muscle, measured in other species for instance, would both support these results obtained and provide more data for a better understanding of metal bioaccumulation processes and transfers in food webs. In addition, in the present study, only species with a relatively high trophic level were considered, thus it would be also highly relevant to examine other species or compartments with lower trophic level such as plankton.

\section{Acknowledgments}

Authors are particularly grateful to the "Agence de l'Eau Rhône Méditerranée Corse" for the financial support of RETROMED project that has allowed to finance Mediterranean analyses. Analyses relative to the $\mathrm{BoB}$ area have been financed by the "Conseil Régional de PoitouCharentes" and the "Contrat de projet Etat-Région" (CPER 2013). We would also like to thank J. Knoery from IFREMER, and P. Richard, G. Guillou and B. Lebreton from the LIENSs laboratory for faciliting trace metal and isotopic analyses, respectively. Thanks are also due to the chief scientists and the crew of the R/V "Thalassa" and "L'Europe" during EVHOE 2008 and MEDITS 2012 surveys as well as to F. Chavanon and C. Ravel for their help during 
sampling and laboratory work. The IUF (Institut Universitaire de France) is also acknowledged

for its support to PB as a Senior Member.

\section{References}

Amiard, J.C., Pineau, A., Boiteau, H.L., Metayer, C., Amiard-Triquet, C., 1987. Application de la spectrometrie d'absorption atomique zeeman aux dosages de huit elements traces ( $\mathrm{Ag}, \mathrm{Cd}, \mathrm{Cr}, \mathrm{Cu}, \mathrm{Mn}, \mathrm{Ni}, \mathrm{Pb}$ et $\mathrm{Se}$ ) dans des matrices biologiques solides. Water Res. 21, 693-697. https://doi.org/10.1016/0043-1354(87)90081-9

Borcard, D., Gillet, F., Legendre, P., 2011. Numerical Ecology with R. Springer.

Bryan, G.W., 1971. The Effects of Heavy Metals (other than Mercury) on Marine and Estuarine Organisms. Proc. R. Soc. Lond. B Biol. Sci. 177, 389-410. https://doi.org/10.1098/rspb.1971.0037

Bryan, G.W., Waldichuk, M., Pentreath, R.J., Darracott, A., 1979. Bioaccumulation of Marine Pollutants. Philos. Trans. R. Soc. Lond. B. Biol. Sci. 286, 483-505.

Canli, M., Atli, G., 2003. The relationships between heavy metal ( $\mathrm{Cd}, \mathrm{Cr}, \mathrm{Cu}, \mathrm{Fe}, \mathrm{Pb}, \mathrm{Zn}$ ) levels and the size of six Mediterranean fish species. Environ. Pollut. 121, 129-136. https://doi.org/10.1016/S0269-7491(02)00194-X

Chouvelon, T., Caurant, F., Cherel, Y., Simon-Bouhet, B., Spitz, J., Bustamante, P., 2014. Species- and size-related patterns in stable isotopes and mercury concentrations in fish help refine marine ecosystem indicators and provide evidence for distinct management units for hake in the Northeast Atlantic. ICES J. Mar. Sci. 71, 1073-1087. https://doi.org/10.1093/icesjms/fst199

Chouvelon, T., Cresson, P., Bouchoucha, M., Brach-Papa, C., Bustamante, P., Crochet, S., Marco-Miralles, F., Thomas, B., Knoery, J., 2018. Oligotrophy as a major driver of mercury bioaccumulation in medium-to high-trophic level consumers: A marine ecosystem-comparative study. Environ. Pollut. 233, 844-854. https://doi.org/10.1016/j.envpol.2017.11.015

Chouvelon, T., Spitz, J., Caurant, F., Mèndez-Fernandez, P., Autier, J., Lassus-Débat, A., Chappuis, A., Bustamante, P., 2012. Enhanced bioaccumulation of mercury in deep-sea fauna from the Bay of Biscay (north-east Atlantic) in relation to trophic positions identified by analysis of carbon and nitrogen stable isotopes. Deep Sea Res. Part Oceanogr. Res. Pap. 65, 113-124. https://doi.org/10.1016/j.dsr.2012.02.010

Cossa, D., Coquery, M., 2005. The Mediterranean Mercury Anomaly, a Geochemical or a Biologocallssue, in: The Mediterranean Sea, Handbook of Environmental Chemistry. Springer, Berlin, Heidelberg, pp. 177-208. https://doi.org/10.1007/b107147

Cossa, D., Harmelin-Vivien, M., Mellon-Duval, C., Loizeau, V., Averty, B., Crochet, S., Chou, L., Cadiou, J.-F., 2012. Influences of Bioavailability, Trophic Position, and Growth on Methylmercury in Hakes (Merluccius merluccius) from Northwestern Mediterranean and Northeastern Atlantic. Environ. Sci. Technol. 46, 4885-4893. https://doi.org/10.1021/es204269w

Cresson, P., Bouchoucha, M., Miralles, F., Elleboode, R., Mahé, K., Marusczak, N., Thebault, H., Cossa, D., 2015. Are red mullet efficient as bio-indicators of mercury contamination? A case study from the French Mediterranean. Mar. Pollut. Bull. 91, 191-199. https://doi.org/10.1016/j.marpolbul.2014.12.005

Cresson, P., Fabri, M.C., Bouchoucha, M., Brach Papa, C., Chavanon, F., Jadaud, A., Knoery, J., Miralles, F., Cossa, D., 2014. Mercury in organisms from the Northwestern Mediterranean slope: Importance of food sources. Sci. Total Environ. 497-498, 229238. https://doi.org/10.1016/j.scitotenv.2014.07.069 
Damiano, S., Papetti, P., Menesatti, P., 2011. Accumulation of heavy metals to assess the health status of swordfish in a comparative analysis of Mediterranean and Atlantic areas. Mar. Pollut. Bull. 62, 1920-1925.

https://doi.org/10.1016/j.marpolbul.2011.04.028

Depledge, M.H., Bjerregaard, P., 1989. Haemolymph protein composition and copper levels in decapod crustaceans. Helgoländer Meeresunters. 43, 207-223. https://doi.org/10.1007/BF02367900

Dural, M., Göksu, M.Z.L., Ozak, A.A., Derici, B., 2006. Bioaccumulation of some heavy metals in different tissues of Dicentrarchus labrax L, 1758, Sparus aurata L, 1758 and Mugil cephalus L, 1758 from the Camlik lagoon of the eastern coast of Mediterranean (Turkey). Environ. Monit. Assess. 118, 65-74. https://doi.org/10.1007/s10661-0060987-7

EC, 2006. COMMISSION REGULATION (EC) No 1881/2006 of 19 December 2006 setting maximum levels for certain contaminants in foodstuffs.

Eisler, R., 2010. Chapter 3 - Fishes, in: Compendium of Trace Metals and Marine Biota. Elsevier, Amsterdam, pp. 39-220. https://doi.org/10.1016/B978-0-444-53439-2.00016-3

El-Moselhy, K.M., Othman, A.I., Abd El-Azem, H., El-Metwally, M.E.A., 2014. Bioaccumulation of heavy metals in some tissues of fish in the Red Sea, Egypt. Egypt. J. Basic Appl. Sci. 1, 97-105. https://doi.org/10.1016/j.ejbas.2014.06.001

Endo, T., Hisamichi, Y., Haraguchi, K., Kato, Y., Ohta, C., Koga, N., 2008. Hg, Zn and Cu levels in the muscle and liver of tiger sharks (Galeocerdo cuvier) from the coast of Ishigaki Island, Japan: Relationship between metal concentrations and body length. Mar. Pollut. Bull. 56, 1774-1780. https://doi.org/10.1016/j.marpolbul.2008.06.003

Espinasse, B., Harmelin-Vivien, M., Tiano, M., Guilloux, L., Carlotti, F., 2014. Patterns of variations in $\mathrm{C}$ and $\mathrm{N}$ stable isotope ratios in size-fractionated zooplankton in the Gulf of Lion, NW Mediterranean Sea. J. Plankton Res. 36, 1204-1215. https://doi.org/10.1093/plankt/fbu043

Fox, J., Weisberg, S., 2011. An \{R\} Companion to Applied Regression.

Glover, J., 1979. Concentrations of Arsenic, Selenium and Ten Heavy Metals in School Shark, Galeorhinus australis (Macleay), and Gummy Shark, Mustelus antarcticus (Günther), from South-eastern Australian Waters. Mar. Freshw. Res. - MAR Freshw. RES 30. https://doi.org/10.1071/MF9790505

Gobert, S., Pasqualini, V., Dijoux, J., Lejeune, P., Durieux, E.D.H., Marengo, M., 2017. Trace element concentrations in the apex predator swordfish (Xiphias gladius) from a Mediterranean fishery and risk assessment for consumers. Mar. Pollut. Bull. 120, 364369. https://doi.org/10.1016/j.marpolbul.2017.05.029

Guven, K., Özbay, C., Ünlü, E., Satar, A., 1999. Acute Lethal Toxicity and Accumulation of Copper in Gammarus pulex (L.) (Amphipoda). Turk. J. Biol. 23, 513-522.

Hall, B.D., Bodaly, R.A., Fudge, R.J.P., Rudd, J.W.M., Rosenberg, D.M., 1997. Food as the Dominant Pathway of Methylmercury Uptake by Fish. Water. Air. Soil Pollut. 100, 1324. https://doi.org/10.1023/A:1018071406537

Harmelin-Vivien, M., Cossa, D., Crochet, S., Bănaru, D., Letourneur, Y., Mellon-Duval, C., 2009. Difference of mercury bioaccumulation in red mullets from the north-western Mediterranean and Black seas. Mar. Pollut. Bull. 58, 679-685. https://doi.org/10.1016/j.marpolbul.2009.01.004

Heimbürger, L.-E., Cossa, D., Marty, J.-C., Migon, C., Averty, B., Dufour, A., Ras, J., 2010. Methyl mercury distributions in relation to the presence of nano- and picophytoplankton in an oceanic water column (Ligurian Sea, North-western Mediterranean). Geochim. Cosmochim. Acta 74, 5549-5559. https://doi.org/10.1016/j.gca.2010.06.036

Hornung, H., Krom, M.D., Cohen, Y., Bernhard, M., 1993. Trace metal content in deep-water sharks from the eastern Mediterranean Sea. Mar. Biol. 115, 331-338. https://doi.org/10.1007/BF00346351 
Jadaud, A., Metral, L., 2012. MEDITS 2012. https://doi.org/10.17600/12060100

Jeffree, R.A., Oberhansli, F., Teyssie, J.-L., 2010. Phylogenetic consistencies among chondrichthyan and teleost fishes in their bioaccumulation of multiple trace elements from seawater. Sci. Total Environ. 408, 3200-3210. https://doi.org/10.1016/j.scitotenv.2010.04.015

Jeffree, R.A., Warnau, M., Teyssié, J.-L., Markich, S.J., 2006. Comparison of the bioaccumulation from seawater and depuration of heavy metals and radionuclides in the spotted dogfish Scyliorhinus canicula (Chondrichthys) and the turbot Psetta maxima (Actinopterygii: Teleostei). Sci. Total Environ. 368, 839-852. https://doi.org/10.1016/j.scitotenv.2006.03.026

Jennings, S., van der Molen, J., 2015. Trophic levels of marine consumers from nitrogen stable isotope analysis: estimation and uncertainty. ICES J. Mar. Sci. 72, 2289-2300. https://doi.org/10.1093/icesjms/fsv120

Leaute, J.P., Salaun, M., Dimeet, J., 2008. EVHOE 2008. https://doi.org/10.17600/8040120 Liénart, C., Savoye, N., Bozec, Y., Breton, E., Conan, P., David, V., Feunteun, E., Grangeré, K., Kerhervé, P., Lebreton, B., Lefebvre, S., L'Helguen, S., Mousseau, L., Raimbault, P., Richard, P., Riera, P., Sauriau, P.-G., Schaal, G., Aubert, F., Aubin, S., Bichon, S., Boinet, C., Bourasseau, L., Bréret, M., Caparros, J., Cariou, T., Charlier, K., Claquin, P., Cornille, V., Corre, A.-M., Costes, L., Crispi, O., Crouvoisier, M., Czamanski, M., Del Amo, Y., Derriennic, H., Dindinaud, F., Durozier, M., Hanquiez, V., Nowaczyk, A., Devesa, J., Ferreira, S., Fornier, M., Garcia, F., Garcia, N., Geslin, S., Grossteffan, E., Gueux, A., Guillaudeau, J., Guillou, G., Joly, O., Lachaussée, N., Lafont, M., Lamoureux, J., Lecuyer, E., Lehodey, J.-P., Lemeille, D., Leroux, C., Macé, E., Maria, E., Pineau, P., Petit, F., PujoPay, M., Rimelin-Maury, P., Sultan, E., 2017. Dynamics of particulate organic matter composition in coastal systems: A spatio-temporal study at multi-systems scale. Prog. Oceanogr. 156, 221-239. https://doi.org/10.1016/j.pocean.2017.03.001

Long, A.M., Wang, W.X., 2005. Metallothionein induction and bioaccumulation kinetics of $\mathrm{Cd}$ and $\mathrm{Ag}$ in the marine fish Terapon jarbua challenged with dietary or waterborne $\mathrm{Ag}$ and Cu. Mar. Ecol. Prog. Ser. 291, 215-226. https://doi.org/10.3354/meps291215

Mason, R.P., 2013. Trace Metals in Aquatic Systems. John Wiley \& Sons.

Mathews, T., Fisher, N.S., 2009. Dominance of dietary intake of metals in marine elasmobranch and teleost fish. Sci. Total Environ. 407, 5156-5161. https://doi.org/10.1016/j.scitotenv.2009.06.003

Mormede, S., Davies, I.M., 2001. Heavy metal concentrations in commercial deep-sea fish from the Rockall Trough. Cont. Shelf Res., The Marine Environment of the North East Atlantic Margin 21, 899-916. https://doi.org/10.1016/S0278-4343(00)00118-7

Ourgaud, M., Ruitton, S., Bourgogne, H., Bustamante, P., Churlaud, C., Guillou, G., Lebreton, B., Harmelin-Vivien, M.L., 2017. Trace elements in a Mediterranean scorpaenid fish: Bioaccumulation processes and spatial variations. Prog. Oceanogr. 163, 184-195. https://doi.org/10.1016/j.pocean.2017.11.008

Papiol, V., Cartes, J.E., Fanelli, E., Rumolo, P., 2013. Food web structure and seasonality of slope megafauna in the NW Mediterranean elucidated by stable isotopes: Relationship with available food sources. J. Sea Res. 77, 53-69. https://doi.org/10.1016/j.seares.2012.10.002

Pohlert, T., 2014. The Pairwise Multiple Comparison of Mean Ranks Package (PMCMR).

$R$ Core Team, 2017. R: A language and environment for statistical computing. $R$ Foundation for Statistical Computing, Vienna, Austria. URL http://www.R-project.org/.

Rainbow, P.S., 2002. Trace metal concentrations in aquatic invertebrates: why and so what? Environ. Pollut. 120, 497-507. https://doi.org/10.1016/S0269-7491(02)00238-5

Rainbow, P.S., 1998. Phylogeny of trace metal accumulation in crustaceans, in: Metal Metabolism in Aquatic Environments. Springer, Boston, MA, pp. 285-319. https://doi.org/10.1007/978-1-4757-2761-6_9 
Raknuzzaman, M., Ahmed, M.K., Islam, M.S., Habibullah-Al-Mamun, M., Tokumura, M., Sekine, M., Masunaga, S., 2016. Trace metal contamination in commercial fish and crustaceans collected from coastal area of Bangladesh and health risk assessment. Environ. Sci.

Pollut. Res. 23, 17298-17310. https://doi.org/10.1007/s11356-016-6918-4

Richir, J., Gobert, S., 2014. A reassessment of the use of Posidonia oceanica and Mytilus galloprovincialis to biomonitor the coastal pollution of trace elements: New tools and tips. Mar. Pollut. Bull. 89, 390-406. https://doi.org/10.1016/j.marpolbul.2014.08.030

Trueman, C.N., MacKenzie, K.M., St John Glew, K., 2017. Stable isotope-based location in a shelf sea setting: accuracy and precision are comparable to light-based location methods. Methods Ecol. Evol. 8, 232-240. https://doi.org/10.1111/2041-210X.12651

Venables, W.N., Ripley, B.D., 2002. Modern Applied Statistics with S. Fourth Edition.

Wang, W.X., 2002. Interactions of trace metals and different marine food chains. Mar. Ecol. Prog. Ser. 243, 295-309. https://doi.org/10.3354/meps243295

$\mathrm{Xu}, \mathrm{Y} .$, Wang, W.X., 2002. Exposure and potential food chain transfer factor of $\mathrm{Cd}$, Se and $\mathrm{Zn}$ in marine fish Lutjanus argentimaculatus. Mar. Ecol. Prog. Ser. 238, 173-186. https://doi.org/10.3354/meps238173

Younis, A.M., Amin, H.F., Alkaladi, A., Mosleh, Y.Y.I., 2015. Bioaccumulation of Heavy Metals in Fish, Squids and Crustaceans from the Red Sea, Jeddah Coast, Saudi Arabia. Open J. Mar. Sci. 05, 369. https://doi.org/10.4236/ojms.2015.54030 
Table 1: Sample description according to ecosystems (Gulf of Lions (GoL) and Bay of Biscay $(\mathrm{BoB}))$ and species, with the sample number $(\mathrm{N})$, the sampling depth range, the total (fish) or cephalothorax (crustacean) length range, and the trophic level range. The number of pools included in the total sample number is indicated between brackets.

\begin{tabular}{|c|c|c|c|c|}
\hline Ecosystem \& Species & $\mathbf{N}$ & $\begin{array}{c}\text { Depth (m) } \\
\text { Mean (min-max) }\end{array}$ & $\begin{array}{c}\text { Length(mm) } \\
\text { Mean (min-max) }\end{array}$ & $\begin{array}{c}\text { Trophic level } \\
\text { Mean (min-max) }\end{array}$ \\
\hline $\begin{array}{l}\text { NW Mediterranean Sea (GoL) } \\
\text { Chondrichthyan fishes }\end{array}$ & 94 & & & \\
\hline Galeus melastomus & $21(6)$ & $\begin{array}{l}520 \pm 190 \\
(284-816)\end{array}$ & $\begin{array}{c}426 \pm 83 \\
(265-558)\end{array}$ & $\begin{array}{c}4.17 \pm 0.28 \\
(3.77-4.82)\end{array}$ \\
\hline Scyliorhinus canicula & $10(1)$ & $\begin{array}{l}470 \pm 163 \\
(284-665)\end{array}$ & $\begin{array}{c}473 \pm 56 \\
(369-569)\end{array}$ & $\begin{array}{l}4.25 \pm 0.11 \\
(4.01-4.44)\end{array}$ \\
\hline \multicolumn{5}{|l|}{ Teleost fishes } \\
\hline Helicolenus dactylopterus & $20(7)$ & $\begin{array}{l}445 \pm 146 \\
(284-679)\end{array}$ & $\begin{array}{c}228 \pm 52 \\
(141-309)\end{array}$ & $\begin{array}{l}3.68 \pm 3.30 \\
(3.3-4.02)\end{array}$ \\
\hline Lepidorhombus boscii & $6(1)$ & $\begin{array}{c}355 \pm 72 \\
(284-426)\end{array}$ & $\begin{array}{c}258 \pm 43 \\
(204-326)\end{array}$ & $\begin{array}{c}3.40 \pm 0.08 \\
(3.32-3.54)\end{array}$ \\
\hline Micromesistius poutassou & 12 & $\begin{array}{c}379 \pm 67 \\
(284-426)\end{array}$ & $\begin{array}{c}256 \pm 29 \\
(222-311)\end{array}$ & $\begin{array}{c}3.54 \pm 0.12 \\
(3.35-3.77)\end{array}$ \\
\hline Phycis blennoides & $20(5)$ & $\begin{array}{l}548 \pm 179 \\
(284-816)\end{array}$ & $\begin{array}{c}254 \pm 50 \\
(196-377)\end{array}$ & $\begin{array}{c}3.76 \pm 0.21 \\
(3.06-4.01)\end{array}$ \\
\hline \multicolumn{5}{|l|}{ Crustaceans } \\
\hline Nephrops norvegicus & $5(2)$ & $\begin{array}{c}426 \pm 0 \\
(426-426) \\
\end{array}$ & $\begin{array}{c}41 \pm 8 \\
(30-50) \\
\end{array}$ & $\begin{array}{c}2.93 \pm 0.07 \\
(2.84-3.03) \\
\end{array}$ \\
\hline $\begin{array}{l}\text { NE Atlantic Ocean (BoB) } \\
\text { Chondrichthyan fishes }\end{array}$ & 58 & & & \\
\hline Galeus melastomus & 12 & $\begin{array}{l}289 \pm 109 \\
(47-337)\end{array}$ & $\begin{array}{c}606 \pm 72 \\
(500-720)\end{array}$ & $\begin{array}{c}4.35 \pm 0.14 \\
(4.06-4.61)\end{array}$ \\
\hline Scyliorhinus canicula & 10 & $\begin{array}{l}126.00 \pm 4 \\
(122-130)\end{array}$ & $\begin{array}{c}579 \pm 30 \\
(530-630)\end{array}$ & $\begin{array}{l}4.45 \pm 0.13 \\
(4.25-4.66)\end{array}$ \\
\hline \multicolumn{5}{|l|}{ Teleost fishes } \\
\hline Helicolenus dactylopterus & 5 & $\begin{array}{c}492 \pm 0 \\
(492-492)\end{array}$ & $\begin{array}{c}370 \pm 20 \\
(340-400)\end{array}$ & $\begin{array}{l}4.09 \pm 0.06 \\
(4.01-4.16)\end{array}$ \\
\hline Lepidorhombus boscii & 5 & $\begin{array}{c}128 \pm 0 \\
(128-128)\end{array}$ & $\begin{array}{c}302 \pm 28 \\
(260-340)\end{array}$ & $\begin{array}{c}3.31 \pm 0.04 \\
(3.25-3.36)\end{array}$ \\
\hline Micromesistius poutassou & 16 & $\begin{array}{l}239 \pm 154 \\
(109-511)\end{array}$ & $\begin{array}{c}250 \pm 48 \\
(200-330)\end{array}$ & $\begin{array}{l}3.91 \pm 0.12 \\
(3.65-4.12)\end{array}$ \\
\hline Phycis blennoides & 5 & $\begin{array}{l}259 \pm 168 \\
(124-461)\end{array}$ & $\begin{array}{c}510 \pm 60 \\
(440-580)\end{array}$ & $\begin{array}{l}4.04 \pm 0.13 \\
(3.9-4.2)\end{array}$ \\
\hline \multicolumn{5}{|l|}{ Crustaceans } \\
\hline Nephrops norvegicus & 5 & $\begin{array}{c}60 \pm 0 \\
(60-60)\end{array}$ & $\begin{array}{c}64 \pm 6 \\
(57-74)\end{array}$ & $\begin{array}{c}2.77 \pm 0.07 \\
(2.65-2.85)\end{array}$ \\
\hline
\end{tabular}


Table 2: Mean metal concentrations taking account of values < LQ (two significant figures) with standard deviation ( $\mu \mathrm{g} . \mathrm{g}^{-1}$ dry mass) in the muscle of the studied species from the Gulf of Lions $(\mathrm{GoL})$ and the Bay of Biscay $(\mathrm{BoB})$. The Trace Element Pollution Index (TEPI) calculated from the same data set is also indicated.

\begin{tabular}{|c|c|c|c|c|c|c|c|}
\hline Ecosystem \& Species & $\begin{array}{c}\text { Ag } \\
\text { Mean } \pm \operatorname{sd~}\left(\mathrm{N}<\mathrm{LQ} \mathbf{Q}_{\mathrm{Ag}}\right) \\
(\min -\mathrm{max})\end{array}$ & $\begin{array}{c}\text { Cd } \\
\text { Mean } \pm \operatorname{sd~}\left(\mathrm{N}<\mathrm{LQ} \mathbf{Q}_{\mathrm{Cd}}\right) \\
(\min -\mathrm{max})\end{array}$ & $\begin{array}{c}\mathrm{Cu} \\
\operatorname{Mean} \pm \operatorname{sd}\left(\mathrm{N}<\mathrm{LQ}_{\mathrm{Cu}}\right) \\
(\mathrm{min}-\mathrm{max})\end{array}$ & $\begin{array}{c}\mathrm{Ni} \\
\operatorname{Mean} \pm \mathrm{sd}\left(\mathrm{N}<\mathrm{LQ} \mathrm{Q}_{\mathrm{Ni}}\right) \\
(\mathrm{min}-\mathrm{max})\end{array}$ & $\begin{array}{c}\text { Pb } \\
\text { Mean } \pm \text { sd }\left(\mathrm{N}<\mathrm{LQ} \mathrm{Q}_{\mathrm{Pb}}\right) \\
(\text { min-max })\end{array}$ & $\begin{array}{c}\mathrm{Zn} \\
\operatorname{Mean} \pm \mathbf{s d}\left(\mathrm{N}<\mathrm{LQ} \mathbf{Q}_{\mathrm{Zn}}\right) \\
(\min -\mathbf{m a x})\end{array}$ & TEPI \\
\hline $\begin{array}{l}\text { NW Mediterranean Sea } \\
\text { (GoL) }\end{array}$ & & & & & & & 1.13 \\
\hline \multicolumn{8}{|l|}{ Chondrichthyan fishes } \\
\hline Galeus melastomus & $\begin{array}{c}0.009 \pm 0.007(21) \\
(0.000-0.020)\end{array}$ & $\begin{array}{c}0.005 \pm 0.006(21) \\
(0.000-0.020)\end{array}$ & $\begin{array}{c}2.3 \pm 2.3(16) \\
(0.8-10.5)\end{array}$ & $\begin{array}{c}0.92 \pm 1.76(14) \\
(0.02-7.00) \\
\end{array}$ & $\begin{array}{c}0.056 \pm 0.068(16) \\
(0.020-0.260)\end{array}$ & $\begin{array}{c}15.6 \pm 1.6(10) \\
(13.0-20.5)\end{array}$ & 1.15 \\
\hline Scyliorhinus canicula & $\begin{array}{l}0.011 \pm 0.010(10) \\
(0.000-0.030)\end{array}$ & $\begin{array}{c}0.009 \pm 0.007(10) \\
(0.000-0.020)\end{array}$ & $\begin{array}{c}1.6 \pm 0.7(9) \\
(0.8-2.6)\end{array}$ & $\begin{array}{c}0.10 \pm 0.10(9) \\
(0.02-0.36)\end{array}$ & $\begin{array}{c}0.034 \pm 0.016(8) \\
(0.020-0.060)\end{array}$ & $\begin{array}{c}31.5 \pm 16.8(3) \\
(12.1-60.3)\end{array}$ & 0.96 \\
\hline \multicolumn{8}{|l|}{ Teleost fishes } \\
\hline Helicolenus dactylopterus & $\begin{array}{c}0.008 \pm 0.006(20) \\
(0.000-0.020)\end{array}$ & $\begin{array}{c}0.011 \pm 0.008(20) \\
(0.000-0.030)\end{array}$ & $\begin{array}{c}1.2 \pm 0.8(17) \\
(0.6-3.2)\end{array}$ & $\begin{array}{c}0.57 \pm 0.67(10) \\
(0.03-2.47)\end{array}$ & $\begin{array}{c}0.044 \pm 0.030(15) \\
(0.020-0.120)\end{array}$ & $\begin{array}{c}18.7 \pm 2.7(2) \\
(13.3-25.1)\end{array}$ & 1.06 \\
\hline Lepidorhombus boscii & $\begin{array}{c}0.008 \pm 0.004(6) \\
(0.00-0.10)\end{array}$ & $\begin{array}{c}0.005 \pm 0.005(6) \\
(0.000-0.010)\end{array}$ & $\begin{array}{c}3.5 \pm 3.9(3) \\
(0.7-10.6)\end{array}$ & $\begin{array}{c}1.61 \pm 2.27(2) \\
(0.09-5.77)\end{array}$ & $\begin{array}{c}0.182 \pm 0.221(3) \\
(0.010-0.580)\end{array}$ & $\begin{array}{c}16.8 \pm 3.3(2) \\
(14.5-23.5)\end{array}$ & 1.19 \\
\hline Micromesistius poutassou & $\begin{array}{c}0.009 \pm 0.003(12) \\
(0.000-0.010)\end{array}$ & $\begin{array}{c}0.003 \pm 0.005(12) \\
(0.000-0.010)\end{array}$ & $\begin{array}{c}2.1 \pm 1.0(8) \\
(0.1-4.2)\end{array}$ & $\begin{array}{c}0.96 \pm 1.35(4) \\
(0.03-4.66)\end{array}$ & $\begin{array}{c}0.028 \pm 0.032(9) \\
(0.000-0.900)\end{array}$ & $\begin{array}{c}18.4 \pm 1.2(0) \\
(16.5-20.5)\end{array}$ & 1.17 \\
\hline Phycis blennoides & $\begin{array}{l}0.014 \pm 0.008(20) \\
(0.010-0.040)\end{array}$ & $\begin{array}{c}0.001 \pm 0.003(20) \\
(0.000-0.010)\end{array}$ & $\begin{array}{l}1.4 \pm 0.7(18) \\
(0.7-3.9)\end{array}$ & $\begin{array}{c}0.24 \pm 0.31(16) \\
(0.03-1.01)\end{array}$ & $\begin{array}{c}0.027 \pm 0.020(17) \\
(0.000-0.070)\end{array}$ & $\begin{array}{c}14.8-1.4(12) \\
(12.3-18.2)\end{array}$ & 1.10 \\
\hline \multicolumn{8}{|l|}{ Crustaceans } \\
\hline Nephrops norvegicus & $\begin{array}{c}1.060 \pm 0.477(0) \\
(0.530-1.640) \\
\end{array}$ & $\begin{array}{c}0.336 \pm 0.266(1) \\
(0.030-0.630) \\
\end{array}$ & $\begin{array}{c}61.9 \pm 25.1(0) \\
(30.2-93.1) \\
\end{array}$ & $\begin{array}{l}0.86 \pm 1.29(2) \\
(0.12-3.15)\end{array}$ & $\begin{array}{c}0.138 \pm 0.136(1) \\
(0.040-0.350) \\
\end{array}$ & $\begin{array}{c}62.1 \pm 9.3(0) \\
(49.9-75.2) \\
\end{array}$ & 1.37 \\
\hline NE Atlantic Ocean (BoB) & & & & & & & 0.70 \\
\hline \multicolumn{8}{|l|}{ Chondrichthyan fishes } \\
\hline Galeus melastomиs & $\begin{array}{l}0.011 \pm 0.005(12) \\
(0.000-0.020)\end{array}$ & $\begin{array}{c}0.005 \pm 0.012(12) \\
(0.000-0.040)\end{array}$ & $\begin{array}{l}0.7 \pm 0.3(12) \\
(0.5-1.7)\end{array}$ & $\begin{array}{c}0.07 \pm 0.09(11) \\
(0.00-0.29)\end{array}$ & $\begin{array}{c}0.042 \pm 0.041(9) \\
(0.020-0.130)\end{array}$ & $\begin{array}{c}10.8 \pm 1.0(12) \\
(10.1-13.7)\end{array}$ & 0.56 \\
\hline Scyliorhinus canicula & $\begin{array}{l}0.012 \pm 0.004(10) \\
(0.010-0.020)\end{array}$ & $\begin{array}{c}0.009 \pm 0.003(10) \\
(0.000-0.010)\end{array}$ & $\begin{array}{c}0.8 \pm 0.3(10) \\
(0.6-1.7)\end{array}$ & $\begin{array}{c}0.16 \pm 0.16(8) \\
(0.06-0.53)\end{array}$ & $\begin{array}{c}0.042 \pm 0.045(8) \\
(0.010-0.160)\end{array}$ & $\begin{array}{c}34.6 \pm 4.2(0) \\
(29.0-40.0)\end{array}$ & 1.00 \\
\hline \multicolumn{8}{|l|}{ Teleost fishes } \\
\hline Helicolenus dactylopterus & $\begin{array}{c}0.026 \pm 0.015(4) \\
(0.010-0.050)\end{array}$ & $\begin{array}{c}0.000 \pm 0.000(5) \\
(0.000-0.000)\end{array}$ & $\begin{array}{c}0.5 \pm 0.1(5) \\
(0.4-0.7) \\
\end{array}$ & $\begin{array}{c}0.01 \pm 0.01(5) \\
(0.00-0.02)\end{array}$ & $\begin{array}{c}0.022 \pm 0.004(5) \\
(0.020-0.030)\end{array}$ & $\begin{array}{c}10.9 \pm 0.4(5) \\
(10.4-11.3)\end{array}$ & 0.37 \\
\hline Lepidorhombus boscii & $\begin{array}{c}0.016 \pm 0.011(5) \\
(0.000-0.030)\end{array}$ & $\begin{array}{c}0.004 \pm 0.005(5) \\
(0.000-0.010)\end{array}$ & $\begin{array}{c}1.6 \pm 2.3(4) \\
(0.5-5.8)\end{array}$ & $\begin{array}{c}0.11 \pm 0.07(5) \\
(0.04-0.22)\end{array}$ & $\begin{array}{c}0.070 \pm 0.106(4) \\
(0.020-0.260)\end{array}$ & $\begin{array}{c}12.7 \pm 2.7(4) \\
(11.4-17.5)\end{array}$ & 0.58 \\
\hline Micromesistius poutassou & $\begin{array}{c}0.012 \pm 0.008(16) \\
(0.000-0.020)\end{array}$ & $\begin{array}{c}0.008 \pm 0.009(16) \\
(0.000-0.030)\end{array}$ & $\begin{array}{c}0.8 \pm 0.2(16) \\
(0.4-1.2)\end{array}$ & $\begin{array}{c}0.05 \pm 0.03(16) \\
(0.00-0.1)\end{array}$ & $\begin{array}{c}0.021 \pm 0.014(15) \\
(0.010-0.060)\end{array}$ & $\begin{array}{c}11.13 \pm 0.99(16) \\
(9.9-13.1)\end{array}$ & 0.63 \\
\hline Phycis blennoides & $\begin{array}{c}0.014 \pm 0.011(5) \\
(0.000-0.030)\end{array}$ & $\begin{array}{c}0.000 \pm 0.000(5) \\
(0.000-0.000)\end{array}$ & $\begin{array}{c}0.49 \pm 0.1(5) \\
(0.4-0.6)\end{array}$ & $\begin{array}{c}0.22 \pm 0.29(5) \\
(0.00-0.07)\end{array}$ & $\begin{array}{c}0.034 \pm 0.026(4) \\
(0.020-0.080)\end{array}$ & $\begin{array}{c}11.26 \pm 0.98(5) \\
(10.3-12.5) \\
\end{array}$ & 0.53 \\
\hline \multicolumn{8}{|l|}{ Crustaceans } \\
\hline Nephrops norvegicus & $\begin{array}{c}0.512 \pm 0.191(0) \\
(0.260-0.730)\end{array}$ & $\begin{array}{c}0.10 \pm 0.05(1) \\
(0.040-0.160)\end{array}$ & $\begin{array}{c}12.6 \pm 4.7(0) \\
(8.2-18.4)\end{array}$ & $\begin{array}{c}0.12 \pm 0.03(5) \\
(0.09-0.17)\end{array}$ & $\begin{array}{c}0.124 \pm 0.038(0) \\
(0.100-0.190)\end{array}$ & $\begin{array}{c}55.2 \pm 3.52(0) \\
(51.0-59.0)\end{array}$ & 0.53 \\
\hline
\end{tabular}

< LQ: under limit of quantification, $\mathrm{LQ}_{\mathrm{Cu}}=2.5, \mathrm{LQ}_{\mathrm{Ni}}=0.25, \mathrm{LQ}_{\mathrm{Zn}}=15, \mathrm{LQ}_{\mathrm{Ag}}=\mathrm{LQ}_{\mathrm{Cd}}=\mathrm{LQ}_{\mathrm{Pb}}=0.05 \mu \mathrm{g} \cdot \mathrm{g}^{-1}$ dry mass. 
Table 3: Variables (Length and Trophic level) and factor (Ecosystem) and their interactions acting on element concentration of the species studied. Results are based only on the element where at least $70 \%$ of concentration were $>$ LQ). For each species and element, effects kept in the selected model during the Akaike information criteria (AIC) are indicated by the F statistic of each tested effect (while respecting marginality of the effects, type-2 tests) presented with numerator d.f. as superscript and denominator d.f. as subscript together with the corresponding P-value. The empty fields are corresponding effects eliminated during the AIC.

\begin{tabular}{|lcccccc|}
\hline \multicolumn{1}{|c}{ Species } & Element & Ecosystem & Length & $\begin{array}{c}\text { Trophic } \\
\text { level }\end{array}$ & $\begin{array}{c}\text { Length } x \\
\text { Ecosystem }\end{array}$ & $\begin{array}{c}\text { Trophic level x } \\
\text { Ecosystem }\end{array}$ \\
\hline $\begin{array}{l}\text { Helicolenus } \\
\text { dactylopterus }\end{array}$ & $\mathrm{Zn}$ & $5.6633_{22}^{1} *$ & $8.2200_{22}^{1} * *$ & & & \\
\hline Scyliorhinus canicula & $\mathrm{Zn}$ & & & & & \\
\hline Nephrops norvegicus & $\mathrm{Ag}$ & $18.1736_{4}^{1} *$ & $6.5326_{4}^{1} N S$ & $15.2856_{4}^{1} *$ & $13.9673_{4}^{1} *$ & $7.0225_{4}^{1} N S$ \\
& $\mathrm{Cd}$ & $4.7296_{4}^{1} N S$ & $1.6923_{4}^{1} N S$ & $5.7189_{4}^{1} *$ & $3.8479_{4}^{1} N S$ & $4.2418_{4}^{1} N S$ \\
& $\mathrm{Cu}$ & $42.8725_{4}^{1} * *$ & $11.5548_{4}^{1} *$ & $13.7228_{4}^{1} *$ & $11.2013_{4}^{1} *$ & $9.6817_{4}^{1} *$ \\
& & & & & \\
& & & & & $2.7431_{6}^{1} N S$ & \\
\hline
\end{tabular}

$* \mathrm{p}<0.05, * * \mathrm{p}<0.01, * * * \mathrm{p}<0.001$, NS not significant. 
Figure 1: Map of the sampling stations in both ecosystems.

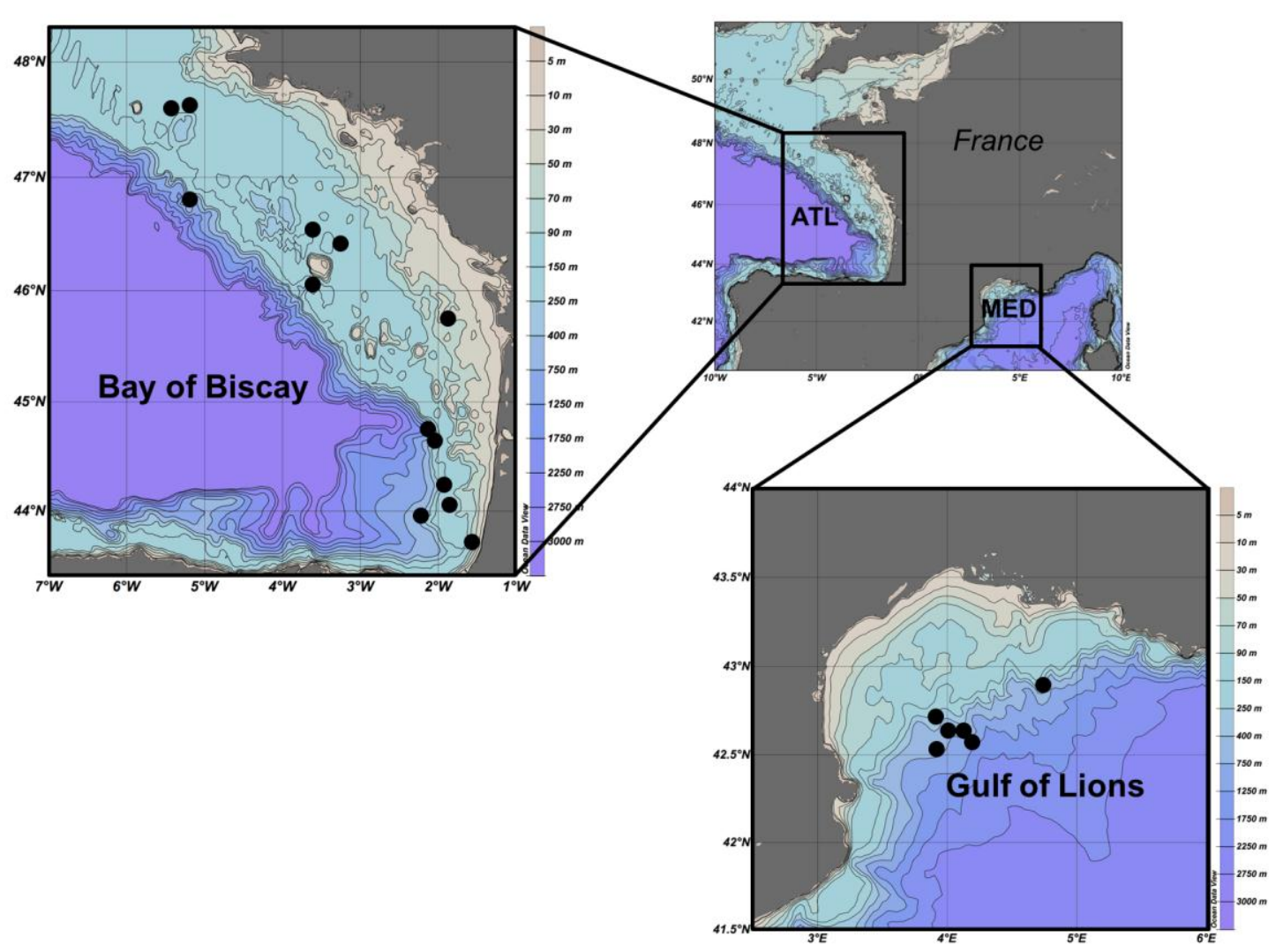


Figure 2: Boxplot of metal concentrations taking account of values < LQ in the muscle ( $\mu \mathrm{g} \mathrm{g}^{-1}$ dry mass), according to the studied species and ecosystem (Bay of Biscay in black and Gulf of Lions in grey). The bottom and top of the box are the first and the third quartiles of the data distribution, the horizontal segment is the median, the whiskers represent the most extreme data point within 1.5 interquartile range and points are data points out of this range.
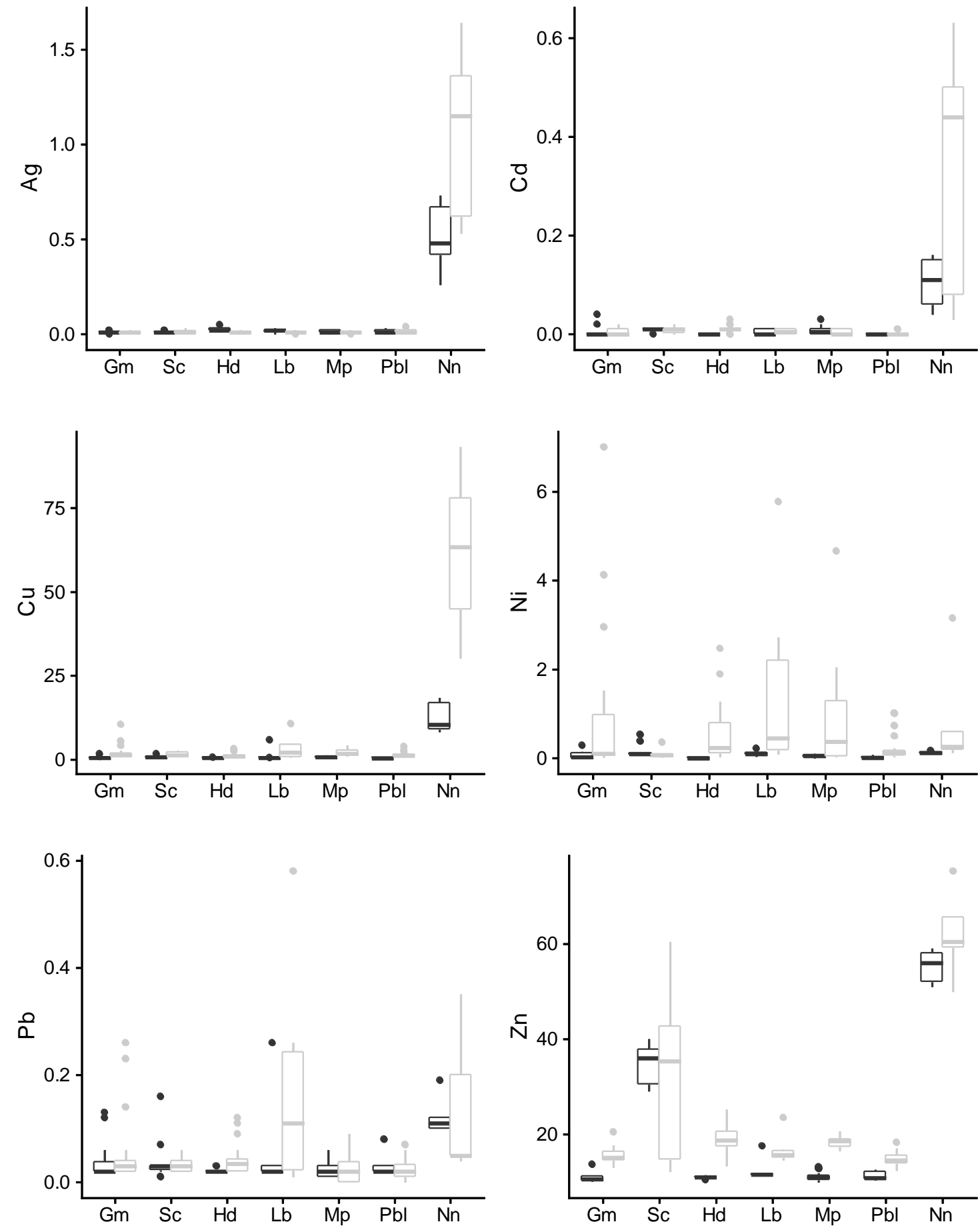

Gm: Galeus melastomus; Sc: Scyliorhinus canicula; Hd: Helicolenus dactylopterus; Lp: Lepidorhombus boscii; Mp: Micromesistius poutassou; Pbl: Phycis blennoides; Nn: Nephrops norvegicus. 